\title{
DA ANGÚSTIA AO MEDO: A EXPERIÊNCIA DO RISCO NA CULTURA CONTEMPORÂNEA
}

From anguish to fear: the experience of tisk in contemporaty culture

CAMILA CALADO ${ }^{1}$

\begin{abstract}
RESUMO: Pesquisa reflete, de modo amplo, sobre como se lida com a finitude na contemporaneidade. Argumenta-se que a cultura do risco, da medicina de caráter preventivo e preditivo, reverte a angústia com a finitude em medo de advento de uma doença determinada. Investiga-se a experiência do risco na cultura contemporânea, ressaltando a convergência entre a experiência de estar sob risco e a experiência da doença crônica e seu caráter de risco. O argumento é desenvolvido a partir da leitura de reportagens da revista $V$ eja sobre mastectomia preventiva, orientada pelas noções de episteme e raridade discursiva de Foucault. Verifica-se o estreitamento dos limites entre normal e patológico, medo da morte, a adoção de um cuidado crônico com a saúde, de práticas de autovigilância no cuidado de si e a realização de intervenções sobre o corpo em condições anteriores ao estado de doença.
\end{abstract}

Palavras-chaves: Finitude. Doença crônica. Risco. Experiência. Subjetividade.

\begin{abstract}
This research analyses how we deal with death in our contemporary culture. We argue that the culture of risk, the preventive and the predictive medicine, determines the anxiety with death in a fear of the advent of certain disease. We investigate the experience of chronic disease in contemporary culture, highlighting the convergence between the experience of being at risk for disease and the experience of disease itself. The argument is developed through readings of Veja magazine reports about preventive mastectomy, guided by Foucault's notions of episteme and discursive rarity. The narrowing of the boundaries between normal and pathological, fear of death, the adoption of chronic health care, self-surveillance practices in self-care and the performance of interventions on the body in conditions prior to the disease state.
\end{abstract}

Key-words: Death. Chronic disease. Risk. Experience.

\section{INTRODUÇÃO}

O modo como habitamos tempo é também o modo como lidamos com nossos sofrimentos e conferimos sentidos para eles. Numa cultura marcadamente cristã, identifica-se uma clara relação

\footnotetext{
${ }^{1}$ Pós-doutorado em Filosofia pela PUC-Rio. Doutorado em Comunicação e Cultura pela UFRJ. Atualmente, é professora substituta do curso de Jornalismo da UFPI e professora colaboradora do Mestrado em Comunicação da mesma instituição. E-mail: c.calado.lima@gmail.com.
} 
causal entre passado e presente. Impera a assertiva nietzschiana: Sofrimento é castigo! Para um sofrimento presente, busca-se uma explicação causal no passado em si mesmo. O indivíduo sofre por não ter contido seus instintos insurgentes a Deus. Memória persistente e explicativa. A interpretação conduz a um novo sofrimento, mais íntimo, mais profundo, mais intenso: a culpa, enquanto emoção moralizante. O sofrimento é interpretado como punição. As fórmulas morais são: sofro por minha culpa; e devo conter-me - seja os instintos pecaminosos e/ou atos imorais no presente para não sofrer no futuro. Com o ascetismo cristão, o presente é lugar de limitação e o futuro de realização.

Quando a ciência passa a ocupar o lugar da ascese, o sentido oferecido pela contenção é o prolongamento da vida e do prazer terreno. A inquietude permanece, mas não mais com o temor do pecado e do além-vida. Não se trataria mais de garantir a salvação do outro mundo, mas de assegurá-la neste mundo terreno. Salvação aqui pode ser entendida como bem-estar, saúde, segurança, esperança de não sofrer... Se o mecanismo de poder reside na adesão ao verdadeiro, destaca Vaz (2002), não importa se o lugar da verdade é ocupado por um padre ou um cientista. De um modo ou de outro, tem-se a padronização de comportamentos. Muda o credor, mantém o lugar da verdade e da moral. O pastor, que dirigia a consciência, agora orienta modos de agir. Passagem da culpa e do pecado para o regime do normal e do patológico. Continua a inquietude com o sentido do sofrimento e com a morte; há, entretanto, uma mudança no modo de endereçamento.

$\mathrm{Na}$ cultura contemporânea, a ciência e a tecnologia vêm provocando inúmeras alterações nos modos de viver e de conceber os processos naturais de nascimento, envelhecimento e morte. Inteligência artificial, engenharia genética, criogenia, farmacopeia antioxidante, backup da mente humana, nanotecnologia, recriação de membros, próteses biônicas, impressoras 3D para recriar partes do coração, animação suspensa... Sob os influxos fáusticos, a tecnociência contemporânea atribui à morte uma capacidade de restauração e adiamento. De um lado, encontra-se, por exemplo, o projeto Reanima com o propósito de "recuperar as funções vitais de indivíduos clinicamente mortos", de "fazer o tempo biológico voltar", como enfatiza Pastor, diretor do projeto (LOIOLA, 2016, p. 100), acompanhando a compreensão de que, como destaca o biólogo inglês Aubrey de Grey, "é patético ver o envelhecimento como natural"; de outro, numa sociedade do controle e do risco, verifica-se a adoção dos preceitos da medicina preventiva e preditiva, num cuidado crônico com a saúde, na ânsia de adiar morte prematura e adoecimento futuro. É sintomático da cultura contemporânea que uma em cada duas mulheres americanas com defeito no gene BRCA se submetam aos procedimentos cirúrgicos de mastectomia simplesmente em caráter preventivo. 
Quando a existência passa a ser especialmente orientada pela ciência e pela técnica, no lugar da angústia, emerge o medo. Determinação da angústia, que tem caráter existencial, em medo de advento de uma doença determinada. Na linha dos pressupostos de Heidegger (2015), o que angustia não é algo que estaria dentro de um sujeito e fora do mundo, é absolutamente indeterminado e, por isso, mesmo tão angustiante. Apenas na angústia é revelado de modo clarividente nosso poder-morrer. O que angustia, destaca Duarte (2017, p. 382, grifo meu), não é a morte como fim futuro, mas "a condição mortal que nos define no presente".

A angústia é apresentada por Heidegger em contraponto ao medo mundano. A distinção evidente é entre o "cuidado ontologicamente vital da angústia" e a "mundanidade negativa do medo" (STEINER, 1990, p. 90). O medo tem como característica a limitação do objeto. O de que se tem medo é sempre um ente intramundano determinado, conhecido, que vem de uma região determinada, se aproxima de modo ameaçador, mas ainda mantém distância, podendo chegar ou não - é nesta aproximação da proximidade que o prejudicial ameaça. O ter medo não provém primeiro da constatação de um mal futuro. Antes de constatar, já há medo. O ente, em seu ser amedrontador, já causa medo. "É tendo medo que o medo pode ter claro para si o de que tem medo" (HEIDEGGER, 2015, p. 200). O pelo que se tem medo é o próprio ente que tem medo. Apenas o ente que, em sendo, coloca em jogo seu próprio ser, pode ter medo. Assim, quando teme por um objeto determinado, no fundo, o ente teme por ele mesmo. "O medo vela, ao mesmo tempo, o estar e ser-em perigo” (HEIDEGGER, 2015, p. 201).

“Medo é angústia imprópria, entregue à decadência do 'mundo' e, como tal, angústia nela mesmo velada" (HEIDEGGER, 2015, p. 256). Medo é angústia velada, porque tenta desviar-se da angústia via a determinação da ameaça. Quando determinamos o quem, o por que, o pelo que, o como, o onde da ameaça, tem-se a sensação de, numa sociedade de controle, de doentes potenciais e sujeitos a risco (DELEUZE, 1992), poder fazer algo a respeito para evitar o evento amedrontador. Aqueles que nos privam da angústia transformando-a em medo, expõe Steiner (1990), afastam-nos da própria vida. Esse lugar de privação pode ser assumido por padres e também por médicos.

A relação entre indivíduo e possibilidade pode ser apreendida historicamente. Em cada época, podem ser identificadas diferentes limitações das possibilidades de ser. Ao compararmos distintas culturas e épocas históricas, é possível nos depararmos com uma diversidade de subjetividades. Na modernidade, Foucault argumenta que havia uma identificação positiva com as figuras do poder pastoral e uma identificação negativa com o anormal, que, na figura do louco, carregava uma íntima associação com a morte. A crença internalizada de que cada indivíduo carregava em seu interior a potencialidade de tornar-se um anormal aparecia como modo de limitação dos possíveis. O temor da anormalidade se desdobrava como inquietação com o próprio 
desejo e como esperança de não sofrer no futuro. Na contemporaneidade, os limites entre normal e patológico são revistos e o anormal passa a abranger quase a totalidade da sociedade, ao mesmo tempo em que o normal se torna idealização. Enquanto a disciplina inquietava-se com a forma dos atos e vinculava a identidade dos indivíduos às preferências por certos desvios, hoje, inquieta o jogo entre hábito e sua consequência, entre prazer e futuro. Neste sentido e levando em conta que uma cultura pode ser definida pelos valores que propõe como positivos, e que emergem por negação da negação, Vaz (2002) argumenta que a passagem da disciplina ao controle é também a passagem do anormal ao risco como conceito a partir do qual se pode pensar a relação dos indivíduos consigo mesmos e com os outros. As limitações contemporâneas se dão, assim, a partir do conceito do risco e das possibilidades de ameaças futuras - no âmbito da saúde: de adoecimento e morte.

A medicina contemporânea ultrapassa o caráter meramente curativo e propõe como meta a prevenção, a identificação e a intervenção técnica anterior ao advento da doença. Enquanto na modernidade o indivíduo buscava o médico a partir do aparecimento dos primeiros sintomas, hoje, com o avanço das tecnologias de diagnóstico e screening, bem como com a descoberta das "doenças silenciosas" - em que a maior parte da população é assintomática ou minimamente sintomática -, verifica-se, mesmo sem a experiência da dor ou do sintoma, a identificação da enfermidade ou da categoria grupo de risco através da avaliação médica, dos exames clínicos, laboratoriais e de imagem, com a consequente classificação dos indivíduos a partir de diretrizes e protocolos clínicos.

Com o mapeamento do genoma, a objetivação do perigo alcança maior percepção e aumenta a incorporação ao indivíduo, articulando predisposição genética a hábitos de vida. $\mathrm{O}$ corpo contemporâneo, "virtualizado na forma de pesquisas sobre riscos associados a predisposições genéticas e hábitos de vida, é um bem a ser administrado" (VAZ, 1999, p. 169). A junção da genética e da epidemiologia perpassa o indivíduo enfermo. Agora, não apenas o indivíduo com problemas de saúde deve cuidar de sua saúde, pois passam a ser reveladas doenças por vir ou em risco. Estados presente e futuro passam a ser discutidos em termos médicos, mesmo sem a experiência de uma doença. No nível do genoma, ninguém é considerado normal, pois estamos todos sob risco, somos todos doentes assintomáticos ou pré-sintomáticos, suscetíveis a tratamento. Somos enquadrados em grupos de risco, pela lógica genealógica ou por uma lógica fatorial combinação de fatores estatísticos associados a uma condição (ROSE, 2009). A probabilidade de concretização de uma predisposição genética pode ser potencializada ou reduzida consoante os hábitos individuais.

Com a lógica do risco, verifica-se um estreitamento dos limites entre normal e patológico, a partir da generalização da anormalidade e do estado de quase-doença, do cuidado crônico e da 
idealização do normal. O normal, hoje, evidencia Vaz (2010), passa a ser não apenas o indivíduo que não apresenta sintomas de doenças, mas aquele que apresenta baixa probabilidade de adoecer, que não sofre e não vai morrer cedo. Para alcançar esta normalidade, o indivíduo precisa inserir-se numa lógica de cuidado crônico, sem limites espaciais e temporais (como se tinha nas doenças infectocontagiosas), de alteração de estilo de vida e de privação de prazeres corporais momentâneos. Ampliam-se as intervenções mesmo sem a experiência da doença. E a experiência de estar sob risco é convergida na experiência da doença em si. A autovigilância via práticas de cuidado de si é, assim, alargada.

A medicina contemporânea - de caráter preventivo e preditivo - antecipa as mais prováveis doenças e formas de morrer, a partir do mapeamento de riscos, indicando, com isso, as limitações que devem ser seguidas no presente, com vistas a reduzir os riscos de contrair doenças futuras e de ter uma morte prematura. Ao estabelecer a noção de morte prematura, a medicina define também a hora certa para morrer. Cabe ao indivíduo, portanto, bem gerir a sua vida para morrer quando a média morre. Este limite temporal pode ser, todavia, constantemente atualizado consoante os avanços da medicina e conforme o comportamento individual - a média de vida de um homem de 60 anos difere se ele é fumante, alcoolista, hipertenso ou se não tem nenhuma doença crônica; de outro modo, os avanços no tratamento do câncer aumentam a sobrevida de novos pacientes.

A mídia evidencia classificações hierárquicas sobre os modos de ser, atribui causalidades entre atos e consequências, bem como estipula responsabilidades individuais e/ou coletivas sobre sofrimentos presentes. Verifica-se uma íntima articulação entre mídia e medicina, de modo que a mídia referenda conhecimentos e verdades sobre os modos de cuidado, através de processos discursivos que estabelecem os comportamentos aceitáveis e fornecem instruções sobre os modos de corrigir os deslizes, com base em configurações historicamente determinadas de saber-poder (FREIRE FILHO, 2008). Identifica-se, assim, uma íntima relação entre mídia e produção de subjetividades. Caráter duplo: de um lado, é proposto o autocontrole sobre opções de prazer no presente que podem expor ao risco; de outro, propõe-se o investimento tecnológico sobre o corpo em caráter preventivo, seja através de check-up, screening, uso de medicamentos, exames ou procedimentos cirúrgicos. Dois núcleos de intervenção na cultura contemporânea: (1) tratar doentes atuais e (2) intervir para evitar o adoecimento futuro, o que conduz à criação da categoria doente virtual ou potencial.

Tendo em mente as reflexões propostas, busca-se realizar a leitura de materiais midiáticos para deles extrair informações, indícios sobre a nossa cultura, sobre as questões e inquietudes colocadas para o sujeito contemporâneo no âmbito dos cuidados com a saúde. Parte-se, assim, da 
análise de reportagens jornalísticas, que propõem regras de conduta, conduzem ao questionamento sobre as ações individuais, produzem subjetividades, geram inquietações no sujeito e constituem um modo de ser técnico. Tais materiais aparecem como o lugar do senso comum, onde se constroi um lugar de ser, propõe-se um dever ser limitado sobre o que é gerir e cuidar da vida, reduzindo assim a abertura de questões sobre o que a vida pode ser.

Para cumprir os objetivos propostos pela pesquisa, propõe-se um estudo qualitativo interpretativo, a partir do método de análise de discursos, na perspectiva de Foucault, com o propósito de investigar como os discursos, por sua vez, construídos a partir da articulação entre saber e poder, produzem subjetividade e visam a construção de verdades científicas sobre os cuidados com a saúde e os modos de lidar com o prazer, o sofrimento e a finitude. Uma questão relevante na reflexão de Foucault (1979) é como discursos impõem-se como a priori histórico. Não era natural e nem evidente que os loucos fossem percebidos enquanto doentes mentais, mas é a partir do momento que emerge o discurso da loucura como anormalidade e que o louco se torna objeto de saber da psiquiatria, que se legitima a adoção de práticas em instituições de cuidado da loucura e dos modos de lidar com o louco na sociedade. Parece, então, fundamental analisar historicamente como são produzidos efeitos de verdade no interior de discursos, que não são em si nem verdadeiros, nem falsos.

Foucault ajuda a refletir acerca da singularidade de nossas crenças, da constituição social dos objetos de conhecimento e dos efeitos de verdade dos enunciados científicos sobre os comportamentos. Parece útil problematizar os enunciados científicos do cuidado de si no limite que os separa do não dito, "na instância que os faz surgirem à exclusão de todos os outros", definindo um sistema limitado de presenças e reconhecendo a posição singular que o enunciado ocupa, consoante o princípio da raridade discursiva (FOUCAULT, 2010, p. 135). Para marcar diferenças entre crenças culturais, cabe ainda considerar a restrição do pensável: não se pode pensar qualquer coisa em qualquer tempo e lugar. Questão fundamental a ser colocada diante de um enunciado: por que precisamente este enunciado, quando tantos outros seriam e já foram possíveis? O princípio aponta, assim, para uma análise histórica do cuidado de si. Pensando a singularidade da cultura contemporânea a partir do conceito de risco, analisou-se as matérias publicadas sobre mastectomia preventiva em Veja, da criação da revista até o ano de 2016.

A relevância da pesquisa consiste, em primeiro lugar, na discussão de aspectos fundamentais da moralidade contemporânea no tocante aos cuidados com a saúde, modo de vida técnica e busca pelo adiamento da morte. Ademais, busca aprofundar as discussões sobre a experiência do risco na cultura contemporânea, refletindo sobre a convergência entre risco e doença crônica, e sobre mídia e produção de subjetividade. A relação 
entre práticas cotidianas e doenças futuras é produzida pela medicina e evidenciada pela mídia. Identifica-se uma relação entre discurso, endereçamento, causalidade e produção de subjetividade. A pesquisa também se faz pertinente para as reflexões sobre o jornalismo, especialmente a partir da discussão do critério de noticiabilidade, que passa cada vez mais a produzir narrativas direcionadas para um público de indivíduos e não de cidadãos. Tem-se uma crescente produção sobre como o indivíduo deve gerir a sua vida, a sua saúde, as suas relações, seu corpo, seu sofrimento, seus medos e seus desejos.

\section{A EXPERIÊNCIA DO RISCO}

A maior prevalência das doenças crônicas, as constantes alterações dos limiares saudável/enfermo, com a inclusão das noções de pré-doença e da categoria sob risco, associada às novas tecnologias de diagnóstico e de screening, provocam alterações na relação do indivíduo com seu corpo, nos modos de pensar sobre si e na experiência da doença. Verifica-se uma mudança não apenas no modo como os processos de saúde e doença são definidos, rotulados e geridos, mas também no modo como são experienciados. A noção de experiência aqui é pensada, a partir de Foucault (1984, p. 10, tradução minha), como "correlação, numa cultura, entre campos de saber, tipos de normatividade e formas de subjetividade"?

A experiência do risco contínuo é cada vez mais evidente em nossa cultura e, atrelado a isso, identificam-se fronteiras menos definidas entre risco e doença na tomada de decisões sobre os cuidados com a saúde, o que está intimamente relacionado ao modo como nomeamos e classificamos risco e doença hoje. A princípio, quando se pensa sobre os conceitos experiência da doença e experiência do risco, entende-se haver diferenças notáveis já que a doença é o processo patológico produzindo problemas de saúde, e o risco é a probabilidade estatística de ocorrência de problemas de saúde. Seguindo este entendimento, não haveria experiência da doença que emanaria do risco. $\mathrm{Na}$ atualidade, entretanto, observa-se que tais fronteiras estão cada vez mais borradas, havendo uma convergência notável entre a experiência de estar sob risco e a experiência da doença (ARONOWITZ, 2009).

Categoriza-se, assim, dois modos centrais de experiência da doença crônica na contemporaneidade: (i) a experiência da doença crônica e seu caráter de risco e (ii) a experiência de estar sob risco convergida na experiência da doença crônica. De um lado, a experiência da doença

\footnotetext{
${ }^{2}$ Texto original: "La corrélation, dans une culture, entre domaines de savoir, types de normativité et forms de subjectivité".
} 
crônica tem se assemelhado cada vez mais à experiência dos indivíduos sob risco. De outro, encontrase maior número de indivíduos mobilizados em torno da probabilidade de aquisição de uma doença e a experiência do risco cada vez mais próxima da experiência da doença em si.

A experiência da doença crônica tem se tornado de risco em função do receio de problemas futuros advindos de intervenções médicas realizadas no tratamento da doença ou do aparecimento de outros problemas patológicos ligados à doença primária. Por exemplo: complicações futuras provenientes de quimioterapia ou radioterapia no tratamento do câncer ou receio de novos cânceres provenientes do tratamento do primeiro. Aronowitz (2009) adota o termo "vida em risco", referindo-se ao medo constante, à contínua autovigilância dos corpos e à crescente demanda por exames e avaliações médicas.

A convergência entre risco e doença crônica pode ser identificada também nos estados de pré-doença, que estabelecem novos limites entre saudável e enfermo, medicalizando o até pouco tempo saudável e estendendo o diagnóstico de doença preexistente para pontos anteriores do diagnóstico natural da doença. A experiência de uma pessoa diagnosticada com pré-diabetes, préhipertensão ou pré-câncer, argumenta Aronowitz (2009), pode ser muito semelhante à experiência do diagnóstico da diabetes, da hipertensão e do câncer.

Aronowitz (2009) narra a história de duas mulheres de 58 anos. Uma lida com o câncer de mama, já tendo sido submetida a cirurgia, radioterapia e quimioterapia. No momento, realiza terapia de antiestrogênio com Tamoxifen e não tem a experiência de nenhum sintoma da doença. Sua preocupação atual é se terá que realizar outra terapia hormonal, após finalizar os cinco anos do seu tratamento, e se ela deveria se submeter a exames de screening e diagnóstico com maior frequência. Para lidar com estes anseios, frequentemente busca informações na internet e participa de grupos de sobreviventes do câncer.

A outra mulher encontra-se sob risco para o desenvolvimento da doença, em virtude do uso continuado de pílula anticoncepcional, da gravidez aos 34 anos, do uso de pílulas de estrogênio desde o aparecimento dos primeiros sintomas da menopausa aos cinquenta anos, e da identificação de anormalidades em um exame de mamografia quatro anos antes, mas que resultou em biópsia negativa. Com medo de desenvolver o câncer de mama, também busca informações em sites e reportagens sobre novas formas de prevenção. Certo dia, viu a propaganda do Tamoxifen (medicamento usado pela primeira mulher) com indicação preventiva para mulheres com alto risco de câncer de mama - categoria em que ela se autoenquadra - e, desde então, vem conversando com médicos, grupos de pacientes e amigos sobre o uso do medicamento.

Uma paciente crônica e uma mulher sob risco experimentam medos do futuro, sentimentos de incerteza e pressões para autovigilância, buscam maneiras de aumentar o controle (ou a sensação 
de controle) sobre a doença e enfrentam decisões difíceis no tocante às novas técnicas de prevenção. A segunda mulher, por exemplo, deve decidir se submeter ou não à mesma terapia hormonal realizada pela primeira. Ambas são submetidas a influências externas comuns no tocante à prevenção e buscam informações em locais semelhantes. Para as duas pacientes, a experiência de enfermidade se dá não a partir de sintomas, mas da leitura do corpo com base em sinais de problemas futuros. Na cultura contemporânea, assintomático não significa ausência de experiência da doença.

A cirurgia profilática, salienta Aronowitz, tem sido realizada em proporções semelhantes por mulheres em diferentes estágios da doença (I, II, III). Num primeiro momento, refletindo sobre os critérios para a tomada de decisão, seria esperado que mulheres com baixa probabilidade de advento do câncer na outra mama realizassem a cirurgia preventiva em números bem inferiores. A questão seria: para que submeter-se a um procedimento tão grande e complexo diante de baixa indicação de seu advento? Numa cultura do risco, entretanto, as decisões racionais orientam-se pela prevenção, pela tentativa de controle sobre a saúde individual e pela expectativa de evitar arrependimentos futuros de não ter feito tudo que estava ao alcance para evitar um evento ruim.

A experiência convergente é ainda refletida na tomada de decisão de mulheres que estão sob risco de desenvolvimento da doença e de mulheres que já manifestaram diferentes estágios do câncer. Corroborando Aronowitz, há razões para acreditar também que a incidência da mastectomia profilática cresceu de modo quase idêntico na decisão de mulheres com alto risco para desenvolvimento do câncer de mama e mulheres diagnosticadas com a doença. Dito de modo mais enfático: a probabilidade de advento futuro do câncer tem orientado mulheres para intervenção técnica em seus corpos de modo semelhante a mulheres que lidam no presente com a doença. Mais uma vez, é interessante perceber como mulheres em diferentes pontos da doença (pré, inicial, avançado) estão inseridas de modo semelhante numa experiência do risco contínuo e adotam estratégias similares para tomada de decisão sobre a intervenção em seus corpos.

Posto isso, analisou-se as matérias jornalísticas publicadas na revista $V$ eja a partir de busca no acervo digital pelas palavras "mastectomia preventiva", com recorte temporal da data de criação da revista até o ano de 2016. A busca resultou em 12 ocorrências, que foram analisadas integralmente, buscando perceber como os argumentos tecnológicos são radicalmente apropriados e construídos pelas pessoas. As análises foram orientadas pelos seguintes temas: quais padrões de comportamento foram valorizados? Quais estilos de vida foram apontados como desviantes? Quais identidades foram definidas como de risco? Quais são os riscos associados à doença virtual? A quem foi atribuída a responsabilidade? Quais conselhos são dados sobre o modo de gerir a vida? Quem está habilitado a aconselhar o cuidado e/ou a mudança de vida? 


\section{A experiência do pré-câncer}

Em 2013, a atriz americana Angelina Jolie realizou mastectomia bilateral em caráter preventivo, tema de reportagem de capa da revista Veja: "Câncer de mama - A escolha de Angelina - a decisão de Angelina Jolie de fazer uma mastectomia preventiva foi um choque e deu o alerta de que, quanto mais cedo agir, melhor" (CUMINALE, 2013). A chamada da reportagem já antecipa o argumento central do texto: a intervenção anterior à descoberta da enfermidade como forma de evitar sofrimentos futuros.

O título da reportagem "O valor maior de Angelina" é complementado pela fotografia da atriz em pé, com a cabeça erguida e o olhar direcionado para frente, para o alto, para o futuro iluminado. Diante da morte de sua mãe e avó por conta dos cânceres de mama e de ovário e da descoberta de uma predisposição genética (o gene 'defeituoso' BRCA) para advento da doença, a atriz decidiu se submeter a uma mastectomia dupla, atitude avaliada, pela revista, como "heroica" e como reflexo dos avanços da medicina na prevenção, detecção e tratamento do câncer de mama.

A retirada das mamas, com todo o imaginário da perda da feminilidade e as alterações que provoca no corpo feminino, é proposta com vistas aos benefícios futuros: mais tempo em vida com a família, o "valor maior de Angelina”. Ela "optou pelo que existe de real valor nesse mundo, a vida e a convivência familiar com o companheiro, o ator Brad Pitt, e os seis filhos" (CUMINALE, 2013, p. 91). A prevenção é a oportunidade de evitar sofrimentos futuros e de ter maior prazer no presente. “[...] Eles sabem que farei qualquer coisa para ficar com eles o maior tempo possível”, comenta a atriz, finalizando a reportagem.

Verifica-se aqui a heroicização da atriz, representada pela figura da mãe heroína que se sacrifica, realizando uma grande intervenção cirúrgica pelos filhos, e também pela figura da atriz que expõe sua privacidade, que torna pública sua escolha, trazendo à tona questões referentes a dimensão estética, a possíveis imperfeições no corpo da atriz - consagrada pela beleza e sedução em suas interpretações cinematográficas - que poderiam afetar contratos milionários, com o intuito de ajudar outras mulheres - e famílias - a não experimentarem a luta contra a doença e o sofrimento que dela decorre, experienciados duas vezes por Jolie.

A escolha de Angelina serve também como um alerta muitas vezes mais poderoso do que aqueles das campanhas tradicionais de prevenção do câncer de mama. A atitude da atriz é uma lembrança de que as mulheres precisam se antecipar à doença - e, em tomando a iniciativa, vão encontrar uma medicina preventiva, de diagnóstico e de tratamento que evoluiu exponencialmente nos últimos anos (CUMINALE, 2013, p. 91-91). 
A partir do conhecimento da mutação genética, o câncer poderia ser evitado e dependeria apenas da escolha individual para realização da cirurgia preventiva. O depoimento de Angelina Jolie descreve a descoberta da predisposição genética como um desafio capaz de ser controlado e que, portanto, não deve provocar sustos. Em suas palavras: “A vida vem com muitos desafios. Aqueles que podemos encarar e sobre os quais podemos ter controle não devem nos assustar". Apenas quatro dias após a cirurgia, a jornalista narra que a atriz já estava animada envolvendo-se em outro projeto de trabalho, reforçando que a cirurgia, além de ser o método mais eficaz, pode ser realizada tranquilamente.

Um infográfico ressalta que a cirurgia preventiva reduz em até $95 \%$ o risco de desenvolvimento do câncer de mama, enquanto a quimioprevenção reduz em 50\%. Expõe que os exames periódicos não reduzem a possibilidade do advento da doença, apenas permitem o rastreamento do câncer em estágio inicial. Nos Estados Unidos, uma em cada duas mulheres com mutação nos genes BRCA opta pela cirurgia; enquanto, no Brasil, a taxa cai para uma em cada cinco. Reitera-se que se trata de um procedimento já comumente adotado pelas americanas, devendo agora ser implementado como procedimento padrão também no Brasil, afinal, anualmente, 53.000 brasileiras são diagnosticadas com câncer de mama e 13.000 casos resultam em óbito (CUMINALE, 2013).

“A angústia e o medo embutidos na escolha de Angelina são difíceis de avaliar por quem nunca esteve na linha de tiro dessa condenação genética à morte. Decidir extirpar as duas mamas é uma maneira radical, mas compreensível de afastar a sentença fatal' (CUMINALE, 2013, p. 91, grifos meu). Não deixa de surpreender a ênfase da reportagem ao associar a predisposição genética à certeza de morte, provocando medo e despertando a necessidade do agir imediato. A antecipação do futuro se dá a partir da herança genética. A angústia com a morte é revertida em medo de advento do câncer - a determinação do medo possibilita uma ação individual no presente. Estabelece-se também uma articulação causal entre sofrimentos passados e a identidade presente. A dor da perda da mãe e da avó e a experiência do sofrimento com o câncer motivaram a atriz a agir preventivamente no presente.

No decorrer da matéria, além do caso da atriz americana, são apresentados outros cinco casos, um de mutação genética e quatro de mulheres que sobreviveram ao câncer. $\mathrm{Na}$ família Mathias Santos, composta por três mulheres, uma filha teve câncer de mama e recupera-se bem, enquanto a mãe e a outra filha foram identificadas com a mutação genética. A mãe se submeteu à mastectomia preventiva e à extirpação dos ovários, mas a filha Camila Santos ainda não se sente segura para realizar a cirurgia, submetendo-se a exames periódicos. " Eu me sinto como se estivesse carregando uma bomba-relógio', define ela. 'Perdi a tranquilidade”'. Novamente: medo e angústia. 
Os outros quatros casos exibem a "batalha vencida" do câncer de mama por mulheres de faixas etárias distintas, que tiveram que se submeter a diferentes tratamentos para enfrentar a enfermidade. Maria Ivanilde Ribeiro, de 60 anos, é enfática: “Estava me preparando pra morrer” (CUMINALE, 2013, p. 96).

O raciocínio construído pela matéria sobre Jolie é: se o câncer é uma doença bastante agressiva que, apesar dos avanços, “ainda continua a desafiar a medicina”, havendo vários casos de óbitos, por que não intervir logo? (CUMINALE, 2013, p. 96). Se você pode agir antes da doença e, com isso, evitar sofrimentos futuros, inclusive o óbito, por que esperar?

A evocação da autoridade científica reforça o argumento. O diretor científico do Instituto Europeu de Oncologia, Umberto Veronesi, diz que para o futuro é preciso focar em três objetivos: a redução na agressividade dos tratamentos, a antecipação no diagnóstico e o aumento da participação das mulheres na identificação precoce. "Se alcançarmos esses objetivos, poderemos chegar a uma mortalidade por câncer de mama próxima de zero nas décadas futuras [...] Participando dos programas de detecção precoce, elas venceram seus medos e conquistaram a própria salvação", comenta Veronesi (CUMINALE, 2013, p. 97). Foco na escolha e na ação individual: elas conquistaram a própria salvação, porque agiram de modo preventivo, optaram pelo cuidado de si.

Em relação às causas do câncer de mama, a matéria cita apenas a predisposição genética, aspecto que, a princípio, independeria da ação individual. Mesmo assim, o foco recai sobre o indivíduo. Apesar de não poder intervir na genética, tem poder de agir sobre suas ações e escolhas no presente - optar pela prevenção - e, com isso, orientar o seu futuro.

A narrativa jornalística apresenta como formas socialmente valorizadas de agir o cuidado crônico com a saúde, a prevenção e a intervenção anterior à doença. Constrói o indivíduo como o responsável pela sua saúde, na medida em que dependeria dele a escolha de cuidar de si e intervir em seu corpo de modo preventivo, para o bem viver e a longevidade. O caso de Angelina Jolie, somado às demais experiências de mulheres com câncer trazidas anteriormente, exemplifica um lado da convergência do risco e da doença crônica: mais pessoas saudáveis inseridas na categoria do risco e o estado de risco em si cada vez mais embodied e mais disease-like (ARONOWITZ, 2009). Só numa cultura do risco é possível a construção de uma matéria jornalística propondo grande intervenção no corpo feminino: uma cirurgia de grande porte, com pós-operatório delicado e doloroso, apenas com fins preventivos. A retirada das mamas foi o foco maior da matéria, mas é citada ainda a importância da extirpação dos ovários, pretendida no momento por Angelina Jolie.

Em dezembro de 2013, uma nota em Veja refere-se ao "efeito Angelina”, termo cunhado para referir-se ao aumento na realização de mastectomias preventivas (UM POUCO..., 2013). Em 
2015, o termo foi recuperado na reportagem que abordava a extirpação dos ovários de Angelina Jolie (CUMINALE, 2015). No box “O efeito Angelina”, é destacado que o número de teste para investigar mutações nos genes BRCA aumentou em 40\% nos Estados Unidos; a busca na internet pelo termo BRCA dobrou após a publicação do primeiro artigo de Angelina; e no Canadá, o número de mulheres encaminhadas para aconselhamento genético aumentou em $90 \%$.

Na reportagem intitulada “Conhecimento é poder”, Cuminale (2015, p. 81) destaca na linha fina que "Angelina Jolie dá a última cartada contra a herança genética que a predispunha ao câncer". Nos termos da atriz, "é possível assumir o controle e enfrentar qualquer problema de saúde" (p. 81). O infográfico da matéria intitulado "Decisão correta" apresenta a prevalência do câncer de mama e de ovário e ressalta graficamente que a dupla mastectomia reduz em 95\% a probabilidade de desenvolvimento do câncer e a cirurgia preventiva do câncer de ovário reduz em $98 \%$ a probabilidade de aparecimento de tumores malignos. A decisão é apresentada como "racional, calculada" e "nada emocional". A mesma avaliação é feita pela leitora Maria Solange Magno, em depoimento publicado na revista Veja: "Mais uma demonstração corajosa e racional de Angelina Jolie. Quando há iminência de um câncer ou até mesmo da morte, consequências e efeitos colaterais tornam-se secundários [...grifo meu]". O conhecimento de que se enquadra nos fatores de riscos para o desenvolvimento de uma determinada doença estreita a relação com a morte, desperta o medo da morte e o desejo de agir para controlar o evento temido. Os depoimentos da atriz e da leitora reforçam como os argumentos tecnológicos são apropriados pelo sujeito contemporâneo na medida em que as intervenções técnicas sobre o corpo são tratadas como decisões racionais, capazes de controlar e orientar acontecimentos futuros.

Em 2016, o historiador Yuval Noah Harari, recuperando o caso de Jolie em artigo da Veja, sinaliza para a mudança na experiência da doença na cultura contemporânea.

As decisões médicas mais importantes em sua vida estão se baseando cada vez mais não em suas sensações de estar doente ou saudável, nem mesmo nos prognósticos de seu médico - mas nos cálculos de computadores que conhecem você melhor do que você se conhece [...] [Angelina Jolie] não se sentia doente, porém decidiu, sabiamente, levar em consideração os algoritmos. 'Você pode não estar sentindo nada de errado', disseram os algoritmos, 'mas há uma bomba tiquetaqueando em seu DNA' (HARARI, 2016, p. 122).

Ordem dos algoritmos: só numa cultura profundamente marcada pela ciência e pela tecnologia isto pode ser escrito.

Em março de 1987, reportagem de Veja narra a história de Regina, mulher de 43 anos. Por ter perdido o pai em decorrência de um câncer, "tinha pavor de um dia também ficar doente". Após o médico identificar nódulos em sua mama, ignorou a orientação para mamografia e realizou 
o exame apenas um tempo depois. Diagnosticada com câncer, o médico informou a necessidade de realização de uma mastectomia, procedimento apresentado pela reportagem como "mutilante" e que "pareceu-lhe tão traumático quanto a notícia da doença". A reportagem apresenta a lumpectomia, a retirada de uma pequena parte da mama, procedimento cirúrgico que traria um "trauma menor" - título do texto (TRAUMA..., 1987). Interessante observar como anos depois a mastectomia começa a ser amplamente praticada não apenas por mulheres pacientes de câncer, mas também por doentes potenciais. Além disso, os exames diagnosticais não passam apenas a serem amplamente recomendados pelos médicos, mas a serem requeridos pelos próprios pacientes, afinal, como expõe a reportagem de Veja em 2015: conhecimento é poder! (CUMINALE, 2015).

A busca no acervo digital da $V e j a$ identificou uma primeira menção à realização de mastectomia preventiva no box de uma reportagem sobre os riscos do silicone à saúde, intitulada "Inimigo do peito", em janeiro de 1992. O texto aborda que o câncer de mama é um dos mais preocupantes problemas de saúde pública dos Estados Unidos, o que tem levado algumas mulheres com história familiar de câncer - geralmente a mãe - à realização da cirurgia. "No Hospital Memorial Sloan-Kettering, de Nova York, vinte mulheres submeteram-se a mastectomia preventiva em 1991". Vinte e um anos depois, os números são outros: uma em cada duas mulheres nos Estados Unidos, consoante Cuminale (2013).

O caso das mastectomias preventivas que começavam a ser praticadas nos Estados Unidos aparece, ainda em 1992, na entrevista "A verdade faz bem" com o oncologista brasileiro Sergio Simon. O jornalista Fabrício Marques explica que se trata da "retirada total do seio completamente sadio antes que o câncer suja" e questiona "não se trata de uma terapia radical demais?". Simon responde:

Não. Na semana passada eu perdi um paciente, vítima de um câncer no intestino. Tinha 40 anos. Seu pai, seu irmão, seus tios e dois primos haviam morrido do mesmo tipo de câncer. Se ele tivesse se submetido a uma cirurgia preventiva e retirado o intestino grosso - deixando apenas o delgado - estaria vivo. Esse tipo de cirurgia é indicado àquelas pessoas que têm uma incidência altíssima de certos tipos de câncer na família, como o de intestino, o de mama e o de ovário. Sabese que são doenças hereditárias e as chances de que também o parente sadio desenvolva o câncer são enormes (SIMON apud MARQUES, 1992, p. 9).

No olho da matéria, é destacada uma frase do Simon que reforça a moral preventiva e a crença no controle: "qualquer câncer pode ser controlado, desde que detectado bem cedo. Mas as pessoas procuram o médico tarde demais". Explica que nos Estados Unidos, metade dos casos de câncer estava sendo curada em virtude das campanhas de diagnóstico precoce. "No Brasil, o câncer é visto como uma fatalidade, as pessoas se comportam como se a morte fosse inevitável" 
(MARQUES, 1992, p. 8). Procuram o médico, complementa, apenas diante do aparecimento dos primeiros sintomas, o que pode ser tarde.

Três anos depois, Veja publica a reportagem “As pistas no álbum de família”, com o relato de casos de mulheres americanas que optaram pela realização da mastectomia preventiva em virtude da herança genética (ALCÂNTARA, 1995). "Fiz tudo que pude para prevenir o câncer [...] Espero que seja o suficiente", afirma Anna Fisher, uma das mulheres que se submeteu ao procedimento cirúrgico após se deparar com os trabalhos da geneticista Mary-Claire King, segundo os quais um em cada dez casos de câncer de mama é provocado pela mutação do BRCA1. Olhando para o passado, constroem-se projeções futuras que orientam o presente.

\begin{abstract}
Histórias como essa mostram o papel cada vez maior que a genética vem ocupando na prática da medicina. Os médicos estão descobrindo que tudo o que acontece com avós, pais, irmãos, tios e primos serve de pistas concretas para diagnosticar e tratar pacientes [...] E a ciência já consegue indicar com espantosa exatidão quais são as probabilidades de cada pessoa pegar uma doença a partir do que aconteceu com seus parentes (faça seus cálculos com a ajuda das tabelas à pág. 86) (ALCÂNTARA, 1995, p. 84).
\end{abstract}

Apresentada a probabilidade de doença, o leitor é convidado a fazer um teste e avaliar suas chances futuras, num caminho para o pré-autodiagnóstico. Esta estratégia facilita a apreensão da moral preventiva e a internalização das preocupações e do medo de advento de uma doença. $\mathrm{O}$ pesquisador Joseph Thompson ressalta: "Numa situação ideal, não somos nós, os médicos, que damos o alerta: é o paciente que nos informa do risco de ter câncer ou de sofrer de enfarte precoce" (ALCÂNTARA, 1995, p. 84). Segundo o pesquisador, uma árvore genealógica da família "pode prolongar a vida de determinadas pessoas em até quinze anos. É um prolongamento e tanto. Especialmente quando se compara com outras estimativas. [...] para muitas pessoas, ficar atento à saúde dos familiares é mais importante do que comer corretamente, exercitar-se e parar de fumar" (ALCÂNTARA, 1995, p. 84). O maior prolongamento da vida se daria pelo cuidado via intervenção de um saber técnico-científico sobre o corpo e não pelos hábitos de vida. Por fim, Alcântara alerta para o momento ideal para procurar um médico: "É aconselhável procurar um médico o mais rápido possível quando um ou mais parentes de primeiro grau (pai, mãe e irmão) tiverem tido o mesmo tipo de câncer ou doença cardíaca grave" (ALCÂNTARA, 1995, p. 90).

Em 2002, a reportagem de Paula Neiva sugere uma "revisão de genes", pois "o peso da genética no surgimento do câncer de mama pode ser menor do que se imaginava". A repórter menciona o fato de muitas mulheres na década de 90 terem realizado a mastectomia preventiva pela descoberta de alterações nos genes BRCA1 e BRCA2. Novo estudo indicava que as cirurgias podem ter sido desnecessárias, não por descartar uma relação entre a doença e os genes defeituosos, mas por sugerir que o fator genético não era tão relevante quanto se imaginava. O texto aponta o 
estilo de vida como fator de grande importância para o desenvolvimento futuro do câncer de mama, atribuindo responsabilidade ao indivíduo pela doença. "O sedentarismo, as dietas ricas em gordura e o excesso de peso funcionam como poderosos gatilhos para o aparecimento da doença - com ou sem risco genético. Evitar um estilo de vida pernicioso é a melhor arma contra o mais comum e letal câncer feminino” (NEIVA, 2002, p. 61).

Em nova reportagem de Neiva (2005), a categoria pré-câncer é apresentada como uma meta ambiciosa da medicina, mas para a qual ainda não haveria um tratamento. Sendo assim, a classificação só serviria para gerar "angústia" (termo da jornalista) nos doentes potenciais. Neiva inclusive aponta que os médicos se questionam até que ponto deveriam informar para uma mulher que ela tem carcinoma in situ, que antecede o câncer de mama, mas não é garantia de seu advento. "Afinal, isso representa uma angústia tão grande que pode levar à antecipação desnecessária de procedimentos como a mastectomia radical, a retirada de parte da mama e a radioterapia" (p. 90). A repórter segue mencionando as cirurgias preventivas realizadas na década de 90 e recupera a pesquisa de 2002, destacando que "parte dessas cirurgias pode ter sido em vão" (p. 92).

Em 2008, a mastectomia preventiva vem à tona novamente, desta vez, acompanhada por uma narrativa de cunho moral preventivo, através da exposição da doença da atriz americana Christina Applegate, diagnosticada com câncer em uma mama e que optou pela mastectomia na outra mama em caráter profilático, seguindo as recomendações médicas em razão da alteração no gene BRCA1 que aumentava de 1 para $60 \%$ suas chances de ter o câncer na segunda mama.

Tendo acompanhado o sofrimento da mãe, que é portadora da mutação genética e já passou por uma mastectomia, dois anos de quimioterapia, oito cirurgias e uma histerectomia (remoção do útero), Christina decidiu pelo caminho mais duro e fez a dupla extirpação no mês passado. "Não queria ter de voltar ao médico a cada quatro meses para testar, apertar, procurar. Só pensei em me livrar da coisa de uma vez", disse ela em entrevista à rede $\mathrm{ABC}$ [...] Para diminuir o risco e a alta ansiedade que o acompanha, Christina removeu as duas mamas, que serão reconstruídas (MOHERDAUI, 2008, p. 111).

A presença dos genes BRCA1 ou BRCA2 também aumenta as chances do câncer de ovário e a recomendação médica é de retirada do órgão. O oncologista Sérgio Simon diz que a maioria das pacientes aceita com tranquilidade a recomendação e conta que praticamente todas as suas pacientes indicadas para cirurgia múltipla realizaram o procedimento completo. Nos Estados Unidos, a mulher que apresenta câncer de mama antes dos 40 anos já realiza o teste genético imediatamente. No Brasil, em virtude do custo elevado $(\mathrm{R} \$ 8.500,00)$, nem todas as pacientes realizam o teste (MOHERDAUI, 2008).

A publicização do câncer de mama por atrizes e cantoras é apresentada pela reportagem como um modo de ajudar "a abrandar o sofrimento emocional das anônimas e a divulgar os 
tratamentos” (MOHERDAUI, 2008, p. 110). Este argumento foi recuperado na reportagem posterior de Lopes (2010, p. 103): “Como os avanços notáveis nos tratamentos estão derrotando o câncer e fazendo com que ele perca a imagem sombria de predador. Para a sua desmitificação, contribuem - e muito - os depoimentos de gente famosa, como José Alencar, Hebe Camargo, Christina Applegate e Lance Armstrong, que resiste à doença com bravura e otimismo”. Otimismo, bravura e, como revelam as fotografias dos quatro pacientes, realização com os avanços científicos no tratamento do câncer, tema central da reportagem. O texto retoma a "decisão radical" de Applegate de realizar a mastectomia preventiva "por ser portadora de uma alteração genética que funciona como uma condenação ao câncer de mama” (p. 106, grifo meu).

"O testamento dentro de cada um" é o título da matéria publicada em 2009 sobre doenças genéticas, incluindo o câncer de mama. Rosenéia Melo é uma brasileira de 55 anos, cuja mãe e irmã morreram "vítimas da doença, com metástase nos ossos, um calvário longo e doloroso. Outras três irmãs também tiveram esse câncer, mas conseguiram flagrar os tumores em fases iniciais - e estão bem. [...] 'Vi minha irmã morrer aos poucos, e não queria o mesmo fim”' (LOPES, 2009, p. 105). Optou pela realização do exame genético e pela mastectomia bilateral em caráter preventivo. Por ser portadora do gene, tinha $85 \%$ de chances de desenvolvimento. Se tivesse optado por tratamentos medicamentosos, o risco de desenvolvimento do câncer cairia para 50\%; com a cirurgia, a probabilidade cai para $1 \%$.

Em todas as reportagens analisadas, a opção pela intervenção cirúrgica é antecedida pela narração da história do doente potencial e do sofrimento experienciado com a doença dos familiares. Em algumas reportagens, é inclusive apresentada a fotografia do doente potencial com o familiar que teve câncer. Essa estratégia retórica constrói uma explicação para a ação do presente com base no sofrimento passado e aponta para a compaixão.

Mas, e quando não há cura nem tratamento para sua predisposição genética? Quando a identificação do risco não possibilita um agir preditivo? Quando não há qualquer possibilidade de controle e de escape da doença? Diante do risco de uma doença neurodegenerativa incurável, doença de Huntington, o plano de Carina Silva, caso o teste desse positivo, era: mais prazer! Voltaria a fumar e abandonaria os estudos para o concurso público. A inquietude prazer versus risco não fazia mais sentido para ela. O estudante Rafael Sibet, de 18 anos, preferiu não se submeter ao teste e não descobrir se desenvolveria o distúrbio na faixa dos 40, 50 anos. " De que adiantaria saber hoje que vou ter essa doença no futuro?', diz. Rafael faz de conta que o risco não existe. [...] Viver exclusivamente o presente é também um bom plano” (LOPES, 2009, p. 108). Quando não há mais o que ser feito sobre o risco futuro, o prazer no presente é valorizado. De todo modo, a resposta mais valorizada é intervir o mais cedo possível. No texto, Lopes narra o caso de pais que, 
com receio de o filho desenvolver a doença com herança genética e incurável do pai, optaram pela fertilização in vitro e implantação dos embriões que não tinham o gene da paramiloidose.

\section{CONCLUSÃO}

As relações de poder podem ser entendidas como interferência contínua no processo de constituição dos indivíduos como sujeitos. Podem ser também caracterizadas como produção de uma economia cognitiva, no duplo sentido do termo economia, vez que propicia a ordenação de si e simplifica o questionamento. "Trata-se de uma estratégia onde o indivíduo pensa a sua singularização a partir das crenças e valores gerados pela sua sociedade” (VAZ, 2002, p. 131). Para tanto, naturalizam-se as crenças e valores, reduzindo possíveis inquietações sobre as diferenças históricas nos modos de pensar e agir, e propõe-se um sentido para a vida, afastando possíveis questionamentos sobre as possibilidades de ser.

Quando a Angelina Jolie opta pela realização de uma mastectomia preventiva, quando inúmeros indivíduos começam a narrar sobre si a partir das categorias de doentes potenciais (prédiabético, pré-hipertenso, pré-câncer) ou quando simplesmente começamos a mudar nossas práticas de alimentação cotidiana (mais salada, menos sal, menos açúcar) acreditamos estar seguindo padrões culturais que nos são colocados ou, de modo imediato, percebemos tais práticas como modos de cuidado e de evitar sofrimentos futuros? Quando o saber técnico-científico propõe caminhos para afastar o sofrimento, para diminuir as probabilidades de adoecimento futuro e morte prematura, o sujeito contemporâneo aceita o investimento sobre o seu corpo e sua vida. Mais que aceitar, requeremos esta intervenção.

Nas reportagens sobre a categoria pré, observa-se a atribuição de responsabilidade ao indivíduo pelos cuidados com a sua saúde, na prevenção da mesma, através de intervenções técnicas sobre o corpo. Sobre a definição de quem está em risco, observa-se um grupo principal: quem tem herança genética. Os riscos retratados são de advento da doença e morte prematura. As orientações das reportagens são: cuidado crônico com a saúde, inserção na lógica de uma medicina preventiva e preditiva, com realização de exames para detecção precoce e acompanhamento de enfermidade, bem como intervenções técnicas para prolongamento da vida. Apesar de não poder intervir na genética, tem poder de agir sobre suas ações e escolhas no presente - optar pela prevenção - e, com isso, orientar o seu futuro. Constrói-se o indivíduo como o responsável pela sua saúde, na medida em que dependeria dele escolher cuidar de si e intervir em seu corpo de modo preventivo, para o bem viver e a longevidade. Identificou-se três principais figuras responsáveis pelo aconselhamento: o médico e/ou cientista, o jornalista e o paciente. Para apresentar o saber 
médico-científico de modo didático, são adotados boxes e infográficos explicativos. Uma estratégia retórica amplamente empregada é o uso de testemunhos e depoimentos de pacientes sobre a experiência da doença real e da potencial, que narram a gestão individual da doença, os sentimentos associados e as decisões tomadas. Esta estratégia aponta tanto para o fazer jornalístico (uso de fontes) quanto para uma característica da nossa cultura: a publicização da dor. É nesta linha que é possível compreender o fato das atrizes Angelina Jolie e Christina Applegate terem exposto publicamente a realização da mastectomia profilática.

A lógica de uma medicina diagnóstica e de screening (pré-requisito para inclusão de indivíduos em estados de risco) depende da crença de que os testes realmente funcionam. Mesmo quando a ciência erra, mantém-se a confiança - ainda que esta seja, por vezes, desestabilizada; mesmo que a ciência ofereça soluções com base na aposta, você aceita a aposta. Além de haver a crença em tais tecnologias, a realização dos testes e a detecção precoce de uma enfermidade ou de um possível advento de uma doença futura transmite aos indivíduos a noção de certo controle sobre a doença. Um dos modos de entender a legitimação da ciência, de seus discursos e suas práticas é a partir do discurso da eficácia e da redução de riscos associada.

Ao analisar as transformações no cuidado de si, pode-se perceber os efeitos que o saber médico-científico, que as verdades científicas e as proposições sobre modos de ser e de evitar sofrimentos, provocam nos modos de agir e pensar sobre si. Nossa cultura é marcada pela crença de que os inúmeros testes diagnósticos, tecnologias de rastreamento, práticas preventivas, modos de gestão da doença com base em riscos futuros e práticas de constante autovigilância e vigilância médica irão tornar as pessoas mais saudáveis e irão reduzir sofrimentos futuros. Diante das incertezas da contemporaneidade, a proposta do cuidado de si, a partir do risco, soa atrativa por sugerir a possibilidade de controlar os processos de saúde/doença e de calcular o futuro. Mas será que, na busca por evitar um sofrimento posterior, não estaria sendo provocado um sofrimento no presente, momento este em que o indivíduo não está sofrendo - não há doença? A produção do risco e a promoção excessiva da eficácia dos correntes esforços de redução do risco parecem ter também custos psíquicos.

\section{REFERÊNCIAS}

ALCÂNTARA, Eurípedes. As pistas no álbum de família. Veja, edição 1397, ano 28, n. 25, jun. 1995, p. 84-90.

ARONOWITZ, R. The Converged Experience of Risk and Disease. The Milbank Quarterly, v. 87, n. 2, p. 2009. 417-442, Disponível em: <http://www.ncbi.nlm.nih.gov/pmc/articles/PMC2728027/>. Acesso em: 20 out. 2014 
CUMINALE, Natalia. “Conhecimento é poder". Veja, edição 2419, ano 48, n. 13, abr. 2015b, p. 80-82.

. O valor maior da Angelina. Veja, edição 2322, ano 46, n. 21, mai. 2013, p. 90-100.

DELEUZE, Gilles. Foucault. Conversações. São Paulo: Ed. 34, 1992.

DUARTE, Pedro. A condição humana. In: NOVAES, Adauto (org.). Mutações: entre dois mundos. São Paulo: Sesc, 2017.

FOUCAULT, Michel. A arqueologia do saber. Rio de Janeiro: Forense Universitária, 2010.

Histoire de la sexualité II: L’usage des plaisirs. Gallimard, 1984.

. Microfísica do poder. Rio de Janeiro: Edições Graal, 1979.

FREIRE FILHO, João. Mídia, subjetividade e poder: Construindo os Cidadãos-Consumidores do Novo Milênio. Lugar Comum: estudos de mídia, cultura e democracia, Rio de Janeiro, n. 25-26, p. 89-103, mai-dez 2008. Disponível em: $<$ http://uninomade.net/wpcontent/files $\mathrm{mf} / 110810120915 \mathrm{M} \% \mathrm{C} 3 \% \mathrm{ADdia} \% 20$ Subjetividade $\%$ 20e\%20Poder\%20-\%20Jo\%C3\%A3o\%20Freire\%20Filho.pdf>. Acesso em: 22 ago. 2015.

HEIDEGGER, Martin. Ser e tempo. Petrópolis: Vozes, 2015.

HARARI, Yuvai Noah. Adeus ao livre-arbítrio. Veja, edição 2510, ano 49, n. 52, dez. 2016, p. 120 123.

LOIOLA, Rita. Está vivo! Veja, edição 2482, ano 49, n. 24, jun. 2016, p. 98-100

LOPES, Adriana Dias. Uma vitória da vida. Veja, edição 2170, ano 43, n 25, jun. 2010, p. $102-$ 108.

108.

O testamento dentro de cada um. Veja, edição 2140, ano 42, n 47, nov. 2009, p. $104-$

MARQUES, Fabricio. A verdade faz bem. Veja, edição 1221, ano 25, n. 7, fev. 1992, p. 7-9.

MOHERDAUI, Bel. A escolha de Christina. Veja, edição 2075, ano 41, n. 34, ago. 2008, p. 110111.

NEIVA, Paula. Entre a saúde e a doença. Veja, edição 1903, ano 38, n. 18, mai. 2005, p. 86-90.

Revisão de genes. Veja, edição 1767, ano 35, n. 35, set. 2002, p. 61.

ROSE, Nikolas. Normality and pathology in a biomedical age. Sociological review, n.57, 2009, p.66-83. Disponível em: < http:/ / eprints.lse.ac.uk/27912/1/Normality\%20and\%20

pathology \%20in\%20a\%20biomedical\%20age\%20(LSERO).pdf>. Acesso em 10 mar. 2015.

STEINER, George. Heidegger. Lisboa: Publicações Dom Quixote, 1990.

TRAUMA menor. Veja, edição 968, mar. 1987, p. 89. 
UM POUCO MAIOR. Veja, edição 2353, ano 46, n. 52, dez. 2013, p. 182.

VAZ, Paulo. A vida feliz das vítimas. In: FREIRE FILHO, João (org.). Ser feliz hoje: reflexões sobre o imperativo da felicidade. Rio de Janeiro: Editora FGV, 2010.

Um corpo com futuro. In: PACHECO, Anelise; COCCO, Giuseppe; VAZ, Paulo. (Org.). O trabalho da multidão. Rio de Janeiro: Gryphus, 2002.

Corpo e Risco. In: VILLAÇA, Nízia; GÓES, Fred; KOSOVSKI, Ester. Que corpo é esse? Novas perspectivas. Rio de Janeiro: Mauad, 1999. 